\title{
Питання психології
}

УДК 159:343.83

DOI: $10.33099 / 2617-6858-2019-53-3-133-140$

Cтріха C. кандидат психологічних наук, старший науковий співробітник иентру воєнно-стратегічних досліджень НУОУ імені Івана Черняховського ORCID ID 0000-0002-5937-7748

Комолаєва T. молодиий науковий співробітник иентру воєнно-стратегічних досліджень НУОУ імені Івана Черняховського ORCID ID 0000-0003-4352-5897

\section{АНАЛІЗ ТЕОРЕТИКО-МЕТОДОЛОГІЧНИХ ПІДХОДІВ ДО ПРОБЛЕМАТИКИ ПРОФЕСІЙНОГО РОЗВИТКУ СПЕЦІАЛІСТІВ}

\begin{abstract}
Стаття присвячена проблематииі розгляду теоретико-методологічних підходів до проблематики професійного розвитку спеціалістів. Головна увага у статті приділясться опису теоретичних надбань науки та висвітленню поглядів вчених на зміст та структуру професійного розвитку спеиіаліста. Увага акиентується саме на розвитку спеціаліста, не орієнтуючись на етап вибору майбутнього фаху, а також на можливості удосконалення відповідного рівня професійної майстерності.
\end{abstract}

Ключові слова: професійний розвиток; якісні характеристики професійної діяльності; конщепиї̈ професійного розвитку та становлення.

Постановка проблеми. Для ефективного виконання професійних функцій будь-який спеціаліст, перш за все, має відповідати тим вимогам професії, в якій він відбувається як фахівець й має потенційні можливості щодо професійного зростання та самовдосконалення.

Разом 3 тим, не кожна людина, що має потенційні можливості (як індивідуально-особистісні, так і функціональні) може, зрештою, стати фахівцем високого класу. Передусім, ми будемо вести мову про одну із головних умов професійного становлення, зростання, а згодом і самовдосконалення індивідуально-психологічних якостей спеціаліста. Однак щоб розглядати ті індивідуально-психологічні якості, що необхідні спеціалісту для ефективного виконання професійних функцій ми маємо визначити підходи щодо проблематики професійного розвитку у науковій літературі загалом.

Аналіз останніх досліджень i публікацій. Проблематикою професійного розвитку спеціалістів займались такі вчені як: Агапов В.С., Деркач А.А., Зазикін В.Г., Зеєр Е.Ф., Кудрявцев Т.В., Мітіна Л.М., Поварьонков Ю.П., Ростунов О.Т., Джон Холланд,
Дональд Сьюпер, Е. Гінцберг та інші автори [1-10].

Мета статті полягає у визначенні поглядів вчених на проблематику професійного розвитку спеціалістів.

Завдання даної статті вирішуються у визначенні, змістовній характеристиці та складових елементах феномену професійного розвитку спеціалістів.

Виклад основного матеріалу. Визначаючи проблематику професійного розвитку особистості Зеєр Е.Ф. феномен професійного розвитку розглядав не лише як вдосконалення, тобто позитивні зміни, а як руйнування виникнення негативних тенденцій та розвитку професійно не бажаних новоутворень. На його думку, професійний розвиток обов'язково супроводжується виникненням професійних деструкцій, що негативно впливають на динаміку розвитку, змінюють профіль особистості та траєкторію професійного життя людини. Саме ці новоутворення $€$ небажаними щодо професійного розвитку та виступають у вигляді психологічних перешкод та бар'єрів. Саме бар'єри стають необхідною умовою професійного розвитку спеціаліста [4].

Професійний розвиток будь-якого спеціаліста відбувається безпосередньо 


\section{Питання психології}

під час професійної діяльності, яка обумовлює собою відповідну взаємодію соціально-економічних, медикобіологічних, психолого-педагогічних та санітарно-гігієнічних особливостей.

У професійній діяльності спеціалістів слід розглядати саме професіоналізм діяльності кожного спеціаліста, який за певних умов розвитку має вдосконалюватись. Розглядаючи сам феномен професіоналізму слід зауважити, що він має обумовлюватись, перш за все, якісними характеристиками професійної діяльності спеціаліста, а саме: високий рівень кваліфікації та компетентності; розвиток професійних умінь та виведення ix на рівень майстерності (тобто оригінального - своєрідного виконання визначених завдань); пошук відповідних рішень та реалізація як повсякденних, так i нестандартних завдань, точність та своєчасність виконання завдань; продуктивність професійної діяльності; стабільність продуктивної діяльності у часі.

Окремо слід сказати про ефективність професійної діяльності спеціалістів, саме тому, що ефективність має бути одним із джерел професійного розвитку. Слід пояснити, чому ми так вважаємо. Перш за все, ефективність професійної діяльності спеціалістів можна визначити як різницю між отриманим кінцевим результатом та тими ресурсами, що були задіяні для досягнення результату.

Ресурси ми можемо поділяти на матеріальні, виробничі та людські. Матеріальні ресурси (у нашому випадку не фінансові) - $є$ тим матеріалом (чи сировиною) 3 якого виготовляється продукція. Виробничі ресурси - це $\epsilon$ засоби виробництва, за допомогою яких матеріал (сировина) має перетворюватись у кінцевий продукт. Людські ресурси $\epsilon$ найціннішим «капіталом» у досягненні кінцевого результату - створення продукту. Залежно від того яким шляхом, при допомозі яких технологій буде створено кінцевий продукт, ми можемо визначити витрати «людського капіталу».
Ми маємо вести мову про те, що саме від якості та сучасності як матеріальних, так і виробничих ресурсів значно залежить якість кінцевого продукту. Проте, на нашу думку, особливу увагу, у нашому випадку слід приділяти саме особистості фахівця. Як людина підходить до виконання, як вона здатна прораховувати можливості виконання визначених завдань, та мінімізувати ризики - залежить здебільшого від неї самої. Іншою мовою, при рівності матеріальних та виробничих ресурсів краще виконують завдання прозорливі, кмітливі та рішучі люди.

За висловом Зеєра Е.Ф. професіоналізм - інтегральна якість (новоутворення) суб'єкта діяльності, що характеризує продуктивне виконання професійних завдань, зумовлене творчою самодіяльністю та високим рівнем професійної самоактуалізації [4].

Зеєр Е.Ф. наголошує на тому, що центральною категорією, яка відображає сутність взаємодії людини та професії - $\epsilon$ професійний розвиток, який у психології розглядається як фундаментальний процес зміни людини. Професійний розвиток, як правило ототожнюється 3 прогресивними змінами людини, а саме дозріванням, формуванням, саморозвитком та самовдосконаленням.

Зміна особистості під час опанування професії відтворюється у поняття професійне становлення та характеризується як індивідуально своєрідний шлях (траєкторію) особистості від початку формування уявлень про професію та професійних намірах по завершенню професійної біографії [4].

Для більш докладного розгляду проблематики професійного розвитку спеціаліста слід приділити увагу саме концепціям самого професійного розвитку.

Згідно кониепиії професійного розвитку Мітіної Л.М., яка грунтується на положеннях концепції Рубінштейна Сергія Леонідовича про два способи життя, розглядаються моделі адаптивної поведінки та професійного розвитку особистості. Визначальним у концепції 


\section{Питання психології}

Мітіної Л.М. є відсутність віку людини з ії професійним розвитком [5].

Автор пропонує модель адаптивної поведінки, вказуючи на те, що у свідомості особистості домінує тенденція до підпорядкування професійної діяльності зовнішнім умовам та обставинам, застосуванню виробленим алгоритмам, шаблонам та стереотипам. Модель нараховує три стадії професійного функціонування, а саме: професійна адаптація; професійне становлення та професійна стагнація. На переконання автора пропонованої моделі, адаптивний тип поведінки $є$ не конструктивним на всіх стадіях моделі.

Модель професійного розвитку передбачає здатність спеціаліста побачити цілісність власної професійної діяльності. Сама модель нараховує три стадії: самовизначення (здатність особистості якісно порівнювати себе 3 іншими та усвідомлювати необхідність змін та перетворень); самовираження (співставлення власної поведінки та мотивації); самореалізація (формування власної життєвої філософії як професіонала, усвідомлення сенсу життя). Професійний розвиток визначається протиріччям між Я - дійсним, відображеним та творчим.

Можна чітко визначити, що пропонуєма модель професійного розвитку Мітіної Л.М. грунтується на відповідному тристоронньому протиріччі особистості, що у підсумку і стимулює людини до професійного розвитку та самовдосконалення.

При розробці кониепиії професійного становлення Кудрявцев T.B. надав великого значення кризовим ситуаціям, що обумовлювались неузгодженістю між очікуваним та досягнутим результатом, зламом старої концепції самого себе та побудовою нової.

Періодизація професійного розвитку визначається віковими межами людини. Автор професійне становлення особистості поділяє на відповідні стадії:

1. Виникнення професійних намірів здійснюється за критерієм соціально- психологічно обгрунтованого вибору людиною відповідної професії.

2. Професійне навчання, метою якого $\epsilon$ репродуктивне засвоєння професійних знань, навичок та вмінь, а критерієм оцінки - професійне самовизначення.

3. Процес активного входження у професію, що визначається за наведеними нижче критеріями: достатньо високі показники професійної діяльності; відповідний рівень розвитку професійно важливих якостей особистості; психологічний комфорт.

4. Повна реалізація особистості у професії. Рівень реалізації визначається тим, що: фахівець не лише опановує операційну сферу на високому рівні, а й використовує творчість у роботі; обирає індивідуальний стиль діяльності; постійно прагне до самовдосконалення [6].

Концеепція Ростунова О.T. Основою даної концепції $є$ створення ефективної системи управління формуванням професійної придатності, під якою розуміється сукупність індивідуальнопсихологічних особливостей людини, що забезпечують найбільшу ефективність іï суспільно корисну діяльність та задоволеність власним трудом. У концепції розглядається формування професійної придатності як систему, що має чотири функціональних блока: професійну орієнтацію; професійний відбір; професійну підготовку та професійну адаптацію. Кожен блок складається 3 декількох підсистем більш низького рівня, що забезпечує функціонування як відповідних підсистем так і всієї системи в цілому [8].

Періодизація професійного розвитку спирається на вік особистості, а стадії професійного розвитку збігаються із стадіями концепцій Кудрявцева Т.В. та Зеєра Е.Ф.

Концепчія Поварьонкова Ю.П. За одиниці періодизації професійного становлення особистості використовуються стадії, періоди та фази. Стадії здебільшого збігаються $з$ етапами професійної соціалізації: допрофесійний розвиток особистості (підготовка до професіоналізації); пошук та вибір 


\section{Питання психології}

професії, навчального закладу; професійне навчання; самостійна професійна діяльність [7].

Самі періоди є компонентами стадій та виникають як результат конкретизації концепції. Автор відокремлює чотири стандартних періоди: професійна адаптація (завершення професійного розвитку попередньої стадіï); стійкий ріст показників; період найвищих досягнень; період спаду, якому може передувати стагнація.

Фази конкретизують ситуацію професійного становлення особистості. Вони пов'язані 3 вирішенням часткових завдань професійного розвитку. Кожен період ділиться на фази, залежно від завдань, що вирішуються: «післявступна ейфорія» та апробація довузівських форм навчальної діяльності; усвідомлення неефективності професійних форм професійної діяльності та формування нових; найвищий розвиток навчальноакадемічної діяльності студента. Хронологічною основою періодизації $\epsilon$ «професійний вік» особистості, а саме тривалість професіоналізації, що виявляється більшою загально трудового стажу.

В даній концепції, основою професійного становлення особистості $\epsilon$ система зовнішніх та внутрішніх факторів, співвідношення яких і визначає базове протиріччя професійного розвитку.

Критеріями професійного становлення за концепцією Поварьонкова Ю.П. є: професійна продуктивність, професійна ідентичність і професійна зрілість.

\begin{tabular}{lcc}
\multicolumn{2}{c}{ Акмеологічна концепщія } & розвитку \\
професіонала має дві & площини \\
представлення & системи & поглядів:
\end{tabular}
змістовну та структурно-процесуальну. Змістовний розвиток «суб'єкта праці» до рівня професіонала розглядається у контексті загального розширення суб'єктного простору особистості, іiі професійного та морального «збагачення». Безпосередньо процесуальний розвиток розглядається з системних позицій, а саме у зв'язку зі змінами і розвитком підсистем професіоналізму особистості та діяльності, нормативного регулювання, мотивації на саморозвиток i професійні досягнення, рефлексивної самоорганізації та в плані розкриття творчого потенціалу особистості [3].

Підсистема

професіоналізму

діяльності характеризується поєднанням високої професійної компетентності із професійними та спеціальними базисними уміннями та навичками. Головним когнітивним компонентом цієї підсистеми, на думку авторів, $є$ професійна компетентність, вказуючи на те, що професіоналізм особистості досягається під час та в результаті розвитку здібностей, професійно важливих i особистісно-ділових акмеологічних якостей, інваріантів професіоналізму, рефлексивної організації та культури, творчого та інноваційного потенціалу, мотивації досягнень, розкриття потенціалу і наявності сильної та адекватної мотивації. Сукупність умов і факторів, що стимулюють особистість до досягнень, утворюють мотиваційну основу розвитку професіонала, якій відводиться важлива роль.

Підсистема

нормативності діяльності та поведінки забезпечує формування професійної та моральної системи регуляції поведінки, діяльності і відносин. Структура системи моральної регуляції діяльності та поведінки у професіоналів відрізняється складністю і включає в себе наступні базисні взаємопов'язані компоненти: мотиваційний (позитивне ставлення до даного виду діяльності, прагнення до самореалізації та досягненням, моральні та професійні установки та інтереси); когнітивний (знання про професійну етику, уявлення про моральність і моральні норми); регулятивний (володіння способами і прийомами, необхідними для розуміння змісту моральних норм i приписів); позиційний (позитивне ставлення до осіб, з якими здійснюються професійні взаємодії, обов'язковість і відповідальність перед ними); емоційновольової (здатність до морального співпереживання, здатність відчувати задоволення від роботи, ініціативність); 


\section{Питання психології}

оцінний або рефлексивний (моральна самооцінка своєї підготовки, результатів діяльності та відносин) [2].

\section{Підсистема}

формування продуктивної Я-концепиії перш за все передбачає розвиток людини у професії до рівня професіонала лише за умови продуктивної

Я-концепції. Сама продуктивна Яконцепція вимагає від людини чітко усвідомити власні уявлення про самого себе свої можливості та подальші перспективи розвитку, завдяки чому людина вибудовує свою взаємодію 3 оточенням налагоджуючи відповідні стосунки 3 ними.

Все це дає особистості можливість створити реальні як особистісні так і професійні стандарти, змоделювати програму власного розвитку та саморозвитку, а також вибудувати гармонійну та продуктивну систему професійної взаємодії з оточенням.

Я-концепцію слід розглядати як цілісний, проте не позбавлений внутрішніх протиріч образ власного «Я». Саме образ власного «Я» стає установкою стосовно самого себе та може включати такі складові елементи:

когнітивний елемент формує образ власних якостей, здібностей, соціальної значущості тощо, та проявляється у самосвідомості особистості;

емоційний елемент передбачає емоційне забарвлення власних дій, що виявляється здебільшого у самоповазі;

оціночно-вольовий елемент визначає прагнення фахівця завоювати повагу серед професійного оточення.

Основою Я-концепції $є$ різноманітні уявлення про самого себе, що відрізняються між собою різним ступенем адекватності та реалістичності, а саме: «Я» реалістичне в теперішньому часі; «Я» ідеальне (тобто до чого прагне людина, ким вона бажає стати орієнтуючись на моральні норми взаємодії 3 іншими фахівцями; «Я» динамічне характеризує спрямованість та наміри особистості щодо майбутнього професійного розвитку; «Я» фантастичне орієнтує особистість у тому якого рівня професіоналом бажав би стати спеціаліст, при наявності умов та можливостей [1].

На думку Зеєра Е.Ф. концептуальними положеннями психології професійного розвитку є: професійний розвиток - мета та цінність професійної культури; професійний розвиток детермінується природно обумовленими, біологічними та соціальними чинниками індивідуальнопсихологічними властивостями індивіда, а також випадковими подіями; професійний розвиток - відкритий та творчий процес; індивідуально-професійний розвиток має власні межі; професійний розвиток супроводжується подоланням зовнішніх та внутрішніх психологічних бар'єрів [4].

Розглядаючи зарубіжні концепції професійного розвитку спеціаліста ми маємо на меті приділити увагу теорії Е. Гінцберга, концепції «кар'єрної зрілості» Дональда Сьюпера та типологічній теорії Джона Холланда.

Теорія E. Гінцберга. Професійний вибір $\epsilon$ достатньо довгим, що може тривати більше десяти років - це процес, що включає в себе низку взаємопов'язаних рішень. Автор акцентує увагу на незворотності цього процесу, тому що попередні рішення обмежують подальші можливості, і закінчується він компромісом між зовнішніми (кон'юнктура, престиж) i внутрішніми факторами (індивідуальні особливості). Вдале самовизначення характеризується наявністю широкого кола особистісно значущих позитивних цінностей або «ціннісної насиченістю», що дає можливість своєрідного маневру, а невдале - вузьким спектром або відсутністю таких цінностей, «ціннісної порожнечею». Основним методом дослідження Е. Гінцберга використав інтерв'ювання. Під час проведення інтерв'ювання фіксувалася емоційна забарвленість проблем, які бачать перед собою підлітки і вирішення яких визначає перебіг професіоналізації. Дослідження автора дали можливість визначати професійний розвиток як послідовність якісно специфічних фаз, де розділовим критерієм виступають зміст i форма 


\section{Питання психології}

переведення індивідуальних імпульсів у професійні бажання. Надалі, грунтуючись на концепції Е. Гінцберга, Дональд Сьюпер створив теорію в якій були враховані деякі недоліки розглянутої концепції: невикористання загальнопсихологічних закономірностей, механічне співвідношення професійних бажань i професійних реалій, недостатність методичного оснащення.

Концепція «кар'єрної зрілості» Дональда Сьюпера. Ця теорія об'єднує феноменологічні концепти і диференційну психологію. Професійний розвиток автор вважає за тривалий, цілісний процес розвитку особистості [9].

Дональд Сьюпер виділяє стадії професійного розвитку, що мають самостійні завдання: «пробудження»; «дослідження»; «збереження»; «зниження». Стадії співвідносяться 3 етапами життєвого шляху, тобто з віком людини. Одночасно 3 поняттям стадіальності автор вводить поняття професійної зрілості, що відноситься до особистості, поведінка якої відповідає завданням професійного розвитку, характерним для даного віку.

Типологічна теорія Джона Холланда. Процес професійного розвитку обмежується визначенням самим індивідом особистісного типу, до якого він належить, пошуком професійної сфери, відповідної до власного типу, вибором одного 3 чотирьох кваліфікаційних рівнів цієї сфери, що визначається розвитком інтелекту i самооцінки [10].

Висновки та перспективи подальших досліджень. Таким чином, розглянувши підходи науковців до такого поняття як професійний розвиток можна зробити такі висновки:

1. Професійний розвиток особистості можна розглядати як комплекс відповідних дій людини, умов та особливостей досягнення визначеної мети на шляху досягнення нею відповідного стану професіоналізму.

2. Складовими елементами професійного розвитку спеціаліста слід вважати: досягнення високого рівня професійної кваліфікації та компетентності; розвиток професійних умінь до рівня майстерності; пошук відповідних рішень та їх реалізація, як у повсякденних, так i y нестандартних ситуаціях; точність та своєчасність виконання завдань; продуктивність професійної діяльності, а також стабільність продуктивної діяльності у часi.

Подальший розвиток проблематики професійного розвитку спеціаліста ми вбачаємо у визначенні необхідних індивідуально-психологічних якостей особистості, що дозволяють йй ефективно виконувати функціональні завдання за посадою.

\section{Список використаних джерел}

1. Агапов В.С. Становление Я-концепции личности: теория и практика. М.: Институт молодежи, 1999. - $164 \mathrm{c}$.

2. Богданов Е.Н. Формирование и развитие профессионально-нравственной культуры будущего учителя: дис. докт. псих. наук / Е.Н.Богданов. - М., 1995. - 594 с.

3. Деркач А.А., Зазыкин В.Г. Акеология. - СПб., 2003. - 256 с.

4. Зеер Е.Ф. Психология профессий: Учебное пособие для студентов вузов. - 2-е изд., перераб., допол. - М.: Академический проект; Екатеринбург: Деловая книга, 2003. - 336 с.

5. Коррекционно-обучающие программы повышения уровня профессионального развития учителя: Уч. пос. - М.: Моск. псих.-соц. ин-т; Воронеж: Изд-во НПО «МОДЭК», 2001. - 188 с.

6. Кудрявцев Т.В. Психология профессионального обучения и воспитания / Т.В.Кудрявцев. М.: Изд-во МЭИ, 1986. - 108 с.

7. Поварёнков Ю.П. Психологическое содержание профессионального становления человека. - М.: Изд-во УРАО, 2002. - 160 с.

8. Ростунов А.Т. Формирование профессиональной пригодности / А.Т.Ростунов. - Минск: Вышэйшая школа, 1984. - 176 с.

9. Super D.E. et al. Vocational Development: A Framework of Research. - New York, 1957. - 142 p.

10. Holland Y.L. Explorations of a theory of vocational choice // J. Appl. Psychol., 1968. V. 52. № 1. 


\section{Питання психології}

\section{References}

1. Agapov V.S. (1999). Stanovleniye Ya-kontseptsii lichnosti: teoriya i praktika. [Self-concept of personality: theory and practice]. M.: Institut molodezhi. - 164 s. (in Russian).

2. Bogdanov E.N. (1995). Formirovaniye i razvitiye professional'no-nravstvennoy kul'tury budushchego uchitelya. [The formation and development of professional and moral culture of the future teacher]: dis. dokt. psikh. nauk / E.N.Bogdanov. - M. - 594 s. (in Russian).

3. Derkach A.A., Zazykin V.G. (2003). Akeologiya. [Akeology]. - SPb. - 256 s. (in Russian).

4. Zeyer E.F. (2003). Psikhologiya professiy. [Psychology of professions]: Uchebnoye posobiye dlya studentov vuzov. - 2-ye izd., pererab., dopol. - M.: Akademicheskiy proyekt; Yekaterinburg: Delovaya kniga. - 336 s. (in Russian).

5. Korrektsionno-obuchayushchiye programmy povysheniya urovnya professional'nogo razvitiya uchitelya. [Correctional and educational programs to increase the level of professional development of a teacher]: Uch. pos. - M.: Mosk. psikh.-sots. in-t; Voronezh: Izd-vo NPO «MODEK», 2001. - 188 s. (in Russian).

6. Kudryavtsev T.V. (1986). Psikhologiya professional'nogo obucheniya i vospitaniya. 「Psychology of vocational training and education]. / T.V.Kudryavtsev. - M.: Izd-vo MEI. - 108 s. (in Russian).

7. Povaronkov Yu.P. (2002). Psikhologicheskoye soderzhaniye professional'nogo stanovleniya cheloveka. [The psychological content of the professional development of man]. - M.: Izd-vo URAO. 160 s. (in Russian).

8. Rostunov A.T. (1984). Formirovaniye professional'noy prigodnosti. [Formation of professional suitability]. / A.T.Rostunov. - Minsk: Vysheyshaya shkola. - 176 s. (in Belarusian).

9. Super D.E. et al. Vocational Development: A Framework of Research. - New York, 1957. - 142 p. (in English).

10. Holland Y.L. Explorations of a theory of vocational choice // J. Appl. Psychol., 1968. V. 52. № 1 (in English).

\section{Резюме}

Стриха С. кандидат психологических наук, старший научный сотрудник иентру военно-стратегических исследований НУОУ имени Ивана Черняховського Комолаева Т. младший научный сотрудник иентру военно-стратегических исследований НУОУ имени Ивана Черняховського

\section{АНАЛИЗ ТЕОРЕТИКО-МЕТОДОЛОГИЧЕСКИХ ПОДХОДОВ К ПРОБЛЕМАТИКЕ} ПРОФЕССИОНАЛЬНОГО РАЗВИТИЯ СПЕЦИАЛИСТОВ

Статья посвящена проблематике рассмотрения теоретико-методологических подходов к проблематике профессионального развития специалистов. Главное внимание в статье уделяется описанию теоретических достижений науки и освещению взглядов ученых на содержание и структуру профессионального развития специалиста. Внимание акцентируется именно на развитии специалиста, не ориентируясь на этап выбора будущей специильности, а также на возможности совершенствования соответствующего уровня профессионального мастерства.

Ключевые слова: профессиональное развитие; качественные характеристики профессиональной деятельности; концепции профессионального развития и становления.

\section{Summary}

Strikha S. candidate of psychological sciences, Senior Researcher Center for Military and Strategic Studies of the National Defence University of Ukraine named after Ivan Chernyakhovskyi

Komolaeva T. Junior Researcher Center for Military and Strategic Studies of the National Defence University of

Ukraine named after Ivan Chernyakhovskyi

\section{ANALYSIS OF THEORETICAL AND METHODOLOGICAL APPROACHES TO ISSUES} OF PROFESSIONAL DEVELOPMENT SPECIALISTS

Introduction. Formulation of the problem. For the effective performance of professional functions, any specialist, first of all, must meet the requirements of the profession in which he will take place as a specialist and has the potential for professional growth and self-improvement. At the same time, each person has potential capabilities (both individual-personal and functional) can, in the end, become a high-class specialist. First of all, we will talk about one of the main conditions for professional formation, growth, and then self-improvement - the individual psychological qualities of a specialist. However, in 


\section{Питання психології}

order to consider those individual psychological qualities necessary for a specialist to effectively perform professional functions, we must determine approaches to the problems of professional development in the scientific literature as a whole.

Purpose. The purpose of the article is to determine the views of scientists on the problems of professional development of specialists. The objectives of this article are solved in the definition, substantive characterization and constituent elements of the phenomenon of professional development of specialists.

Methods. The article is devoted to the issue of review of theoretical and methodological approaches to issues of professional development specialists. The focus of the article on describing the theoretical achievements of science and scientists coverage views on the content and structure of professional development specialist. Attention is focused on the development of a specialist is not focusing on the stage of choosing a future profession, as well as the possibility of improving the appropriate level of professional skills.

Originality. Statement of the main material. The professional development of any specialist occurs directly during professional activity, determines the appropriate interaction of socio-economic, biomedical, psychological, pedagogical and sanitary-hygienic features. In the professional activity of a specialist, it is precisely the professionalism of the activity of each specialist that should be improved under certain development conditions. Considering the phenomenon of professionalism itself, it should be noted that it is determined, first of all, by the qualitative characteristics of the professional activity of a specialist, namely: high level of qualification and competence; the development of professional skills and bringing them to the level of skill (that is, original - a kind of specific tasks); search for appropriate solutions and implementation of both everyday and non-standard tasks, accuracy and timeliness of tasks; professional performance; stability of productive activity over time. Separately, it should be said about the effectiveness of professional activities of a specialist, precisely because effectiveness should be one of the sources of professional development. It should be explained why we think so. First of all, the effectiveness of a specialist's professional activity can be defined as the difference between the final result obtained and those resources that were used to achieve the result. We can divide resources into material, production and human. Material resources (in our case, financial) are the material (or raw materials) from which the products are made. Productive resources are the means of production by which the material (raw material) must be transformed into the final product. Human resources are the most valuable "capital" in achieving the final result - the creation of a product. Depending on which way, with the help of which technologies the final product will be created, we can determine the costs of "human capital". We must talk about the fact that the quality of the final product largely depends on the quality and modernity of both material and production resources. However, in our opinion, in our case, special attention should be paid specifically to the personality of a specialist. How a person approaches execution, how he is able to calculate the ability to perform certain tasks, and minimize risks - depends mainly on him-self. In another way, with the equality of material and production resources, it is better for the tasks of visionary, quick-witted and decisive people.

Conclusions and prospects for further research. Thus, having examined the approaches of scientists to such a concept as professional development, the following conclusions can be drawn:

1. Professional development of an individual can be considered as a complex of a person's response, conditions and characteristics of achieving a specific goal on the way to achieving an appropriate state of professionalism.

2. The following should be considered as components of professional development of a specialist: achievement of a high level of professional qualification and competence; development of professional skills to the level of mastery; search for appropriate solutions and their implementation, both in everyday and in non-standard situations; accuracy and timeliness of tasks; the productivity of professional activities, as well as the stability of productive activities over time.

We see the further development of the problems of professional development of a specialist in determining the necessary individual psychological qualities of a person that enable her to efficiently perform functional tasks according to her position.

Key words: professional development; quality characteristics of professional activity; professional development and concept formation. 